\title{
The effect of changes in ownership structure on performance: Evidence from the thrift industry *
}

\author{
Rebel A. Cole \\ Board of Governors of the Federal Reserve System, Washington, DC 20551, USA \\ Hamid Mehran \\ Northwestern University, Evanston, IL 60208-2001, USA
}

\begin{abstract}
Restrictions on the ownership structure of a public company may harm the company's performance by preventing owners from choosing the best structure. We examine the stock-price performance and ownership structure, before and after the expiration of anti-takeover regulations, of a sample of thrift institutions that converted from mutual to stock ownership. We find that after the anti-takeover provisions expire, firm performance improves significantly, and the portions of the firm owned by managers, noninstitutional outside blockholders, and the firm's employee stock ownership plan increase. Changes in performance are positively associated with changes in ownership by managers and by noninstitutional outside blockholders but negatively associated with changes in ownership by employee stock ownership plans.
\end{abstract}

Key words: Corporate control, Regulation, Ownership structure, Anti-takeover provisions JEL classification: $\mathrm{G} 21, \mathrm{G} 28, \mathrm{G} 32, \mathrm{G} 38$

Correspondence to: Rebel A. Cole, Mail Stop 90, Board of Governors of the Federal Reserve System, Washington, DC 20551, USA. E-mail to m1rac01@frb.gov

* We thank George Aragon, Mark Flannery, Alvin Harrel1, Clifford G. Holderness, Edith Hotchkiss, Michael Jensen (the editor), Edward J. Kane, Donald May, Marcia Millon Cornett, Manju Puri, Henri Servaes, Robert Taggert, Hassan Tehranian, Thomas Vartanian, William Wilhelm, Julie Williams, an anonymous referee, and seminar participants at Boston University, Suffolk University, University of Massachusetts at Amherst, and Columbia University for helpful discussion of this study. Earlier versions of this paper were presented at the 1995 annual meetings of the Western Finance Association and the Financial Management Association and at the 1996 annual meeting of the American Finance Association. The analysis and conclusions in this article are of those of the authors and do not indicate concurrence by the Board of Governors or the Federal Reserve System. 


\section{The effect of changes in ownership structure on performance: Evidence from the thrift industry}

\section{Introduction}

The separation of ownership and control in corporations and the resulting reduction in firm performance have recently reengaged researchers' attention (see, for example, the January/March 1988 special issue of the Journal of Financial Economics.) Their concern is due to shareholders' loss of control over the managers of public corporations, who are then able to pursue their own interests rather than those of the shareholders.

In this study, we investigate the relationship between ownership structure and firm performance during 1987-93 using a sample of 88 thrift institutions that converted from mutual to stock ownership in 1983-87. We focus on the thrift industry for two reasons. The first is related to a provision of Federal Home Loan Bank Board mutual-to-stock conversion regulations known as the Post-Conversion Anti-Takeover Rule which prohibits any insider or outsider from owning more than $10 \%$ of a converting thrift's equity for three to five years following conversion. The restriction on outside ownership at the very least protects incumbent managers from the discipline of the market for corporate control (e.g., Jensen and Ruback, 1983). It can also prevent a recently converted institution from choosing the optimal percentage of insider ownership, weakening managerial incentives (e.g., Jensen and Murphy, 1990). Thus, regulation of the firm's ownership structure has the potential to hurt shareholders by motivating insiders to deviate from value-maximizing decisions.

The second, but less important, reason for focusing on the thrift industry is that it allows us to better control for intra-industry differences across firms. The production technology and accounting practices of firms in the thrift industry are far more homogeneous than those of firms in other industries. Homogeneity of production technology is ensured by 
the qualified thrift lender (QTL) test imposed by regulators on thrifts, which requires them to hold at least $60 \%$ of their "portfolio" assets in residential mortgages, mortgage-backed securities, and other narrowly specified asset classes to be able to borrow from a Federal Home Loan Bank (FHLB). FHLB advances, as these loans are known, allow a depository institution to obtain funds at rates below those available in the marketplace, and are the major advantage of belonging to the FHLB system. Homogeneity of accounting practices is a function of additional regulations requiring each thrift to file a comprehensive and standardized report of income and condition, equivalent to a balance sheet and income statement, on a quarterly basis.

We find a significant increase in the percentage of the firm owned by the largest inside stockholder and a significant improvement in firm performance after the anti-takeover provisions expire. Moreover, the greater the increase in insider ownership, the greater the improvement in performance. The latter finding is consistent with Jensen and Meckling (1976) and Kane (1995), who suggest that managers' incentives to maximize shareholder value increase with their ownership stake. ${ }^{1}$

We also find that the portions of the firm owned by the largest noninstitutional blockholder and by the firm's employee stock ownership plan increase significantly after the anti-takeover provisions expire. Moreover, changes in firm performance are positively associated with changes in ownership by the largest noninstitutional blockholder but

\footnotetext{
1 Managers can increase shareholder value in at least two ways. First, they can reduce excess perquisite consumption, and second, they can invest in riskier assets, effecting wealth transfers to shareholders from creditors, including the deposit insurance fund. See Kane (1995) for a general discussion. Our findings do not differentiate between the two.
} 
negatively associated with changes in ownership by employee stock ownership plans. The former finding is consistent with Jensen and Ruback's (1983) view that the market for corporate control plays a disciplinary role; the latter finding is consistent with the view that employee stock ownership plans are often used to impede takeovers. We do not find that the largest institutional blockholders, on average, adjust their share holdings after the antitakeover provisions expire, nor do we find a link between ownership by the largest institutional blockholders and firm performance.

Our findings have several important research and policy implications. First, they provide a direct response to questions raised by Jensen and Warner (1988, p. 13-14) in their summary of the findings of cross-sectional studies testing the relation between insider ownership and firm value. Jensen and Warner indicate that the empirical estimates of the relation are not resolved because the studies treat ownership as exogenous. ${ }^{2}$ They also point out that previous studies do not explain why ownership concentration is not chosen to maximize firm value. Evidence presented here suggests that ownership is endogenous. Our findings also provide empirical evidence regarding the effects on performance of political and legal restraints on ownership and control in support of Roe (1990). Third, our findings extend the literature establishing the effects of ownership on firm performance, which with a few exceptions has ignored financial institutions. ${ }^{3}$ Fourth, our findings have significant

\footnotetext{
2 A number of authors have argued that the firm's ownership structure is endogenous. See, for example, Demsetz (1983) and Fama and Jensen (1983).

3 Masulis (1987) examines the mutual-to-stock conversion process for thrift institutions and concludes "that, on average, all the major claimants in the [mutual savings and loans] choosing to convert to stock charter gain from this action." Esty (1993) reports a positive relationship between insider ownership and firm risk-taking.
} 


\section{$-4-$}

implications for the regulation of depository institutions: By providing a better understanding of managerial incentives and disincentives, they should help regulators and lawmakers as they evaluate competing arguments about how to achieve a stronger, more competitive financial system.

Finally, our results have important implications for research in the efficiency and expense preference behavior of mutual versus stock charter thrifts (e.g., Mester (1991) and Hermalin and Wallace (1994)). Studies that analyze stock thrifts prior to expiration of antitakeover provisions can understate the efficiency and performance of stock-charter thrifts.

The next section discusses in some detail the effect of regulation on firm ownership and performance. Section 3 describes our data and methodology, and section 4 presents our results. Section 5 summarizes and concludes the paper.

\section{The Post-Conversion Anti-Takeover Rule}

The Post-Conversion Anti-Takeover Rule ("the Rule") governed the conversion of thrift institutions insured by Federal Saving and Loan Insurance Corporation (FSLIC) during the 1980 s, and has continued to govern the conversion of thrifts insured by the Savings

Neither author, however, addresses the effect of anti-takeover provisions on the ownership structure and performance of the converted stock institutions.

In two other studies, Crawford, Ezzell, and Miles (1995) and Hubbard and Palia (1995) examine the effect of deregulation of interstate banking during the 1980s on pay-performance sensitivity of CEOs. They find an improvement in payperformance sensitivity after deregulation and increases in both insider ownership and the use of equity-based compensation. In contrast to those studies, which focus on the effect of the relaxation of restrictions on the firm's investment and operating policies, we study the effect of the relaxation of restrictions on the firm's ownership and compensation structures. 
Association Insurance Fund (SAIF) since the FSLIC's demise in 1989 (12 C.F.R. $§ \S 563$ b 1.40 (1986), originally adopted in 1976.). The Federal Home Loan Bank Board (FHLBB) adopted the Rule in 1976, when that agency interpreted the expiration of a congressionally mandated moratorium on mutual-to-stock conversions as granting it authority to authorize and oversee conversions of federally chartered mutual thrifts to federal stock thrifts. ${ }^{4}$ Adoption of the Rule effectively ended a 24-year moratorium on mutual-to-stock conversions by thrift institutions. In encouraging such conversions, Congress and the FHLBB sought to attract private capital to an industry that Kane (1983) estimates was insolvent by $\$ 42$ billion at the end of 1976.

The Rule prohibits any person from directly or indirectly acquiring more than $10 \%$ of the beneficial ownership of any class of equity of an FSLIC-insured savings institution converted in accordance with the FHLBB's Conversion Regulation for a period of three years following completion of the conversion without prior written approval of the FHLBB (12 C.F.R. $\S 563$ b.3(i)(7)). The Rule covers stock options, warrants, or other rights to purchase any class of equity securities, and any securities convertible into equity securities. The equity

4 The congressionally mandated moratorium, imposed in August 1973 through enactment of Pub. L. No. 93-100, substituted a statutory moratorium on conversions for a pre-existing FHLBB administrative moratorium. The congressional moratorium, which originally lasted through June 1974, was extended in October 1974 (Pub. L. No. 93-495) until June 1976. The FHLBB interpreted the expiration of the congressionally mandated moratorium in June 1976 as granting it full authority to approve and regulate conversions. Others interpreted the expiration as removing the FHLBB's previously limited authority over such conversions, and several lawsuits ensued. The FHLBB's authority ultimately was upheld by the courts. See Williams, Fleck, and Comizio (1987, pp. 238-248) for a lucid discussion of the controversy and its resolution. Congress officially ended the moratorium for federally charter thrifts in a provision of the Garn-St Germain Depository Institutions Act of 1982. 
securities need not have voting rights to be covered by the Rule (see Williams (1994, pp. 782) for discussion). The term "person" is defined to include "an individual, a group acting in concert, a corporation, a partnership, an association, a joint stock company, a trust, an unincorporated organization or similar company, a syndicate or any other group formed for the purpose of acquiring, holding, or disposing of securities of an insured institution". (See Williams, Fleck, and Comizio (1987, p. 297)). Hence, the combined ownership of any group of shareholders acting in concert-including managers, their families, and their outside business partners is limited to $10 \%$.

A key issue in the application of the Rule is the way in which the term "acting in concert" is defined. For purposes of the Rule, a group is considered to be acting in concert when "participants are aware of the common design and knowingly participate therein" (12 C.F.R. $\S 563$ b.3(i)(8)(i) (1986) and 12 C.F.R. $§ 574.2(c)$.$) Hence, the limitation generally$ does not apply to managers or directors as a group unless they knowingly act as a group, but the decision of when the limitation does apply is ultimately left to the courts. Note, however, that a thrift's tax-qualified employee stock benefit plan may acquire up to $25 \%$ of any class of the institution's equity without prior approval of regulators (12 C.F.R. $\S 563$ b.3(i)(5)(v)).

The Rule also allows a converting thrift to include in its new stock charter provisions that prohibit, for a period of up to five years, (1) an offer to acquire or an acquisition of more than $10 \%$ of the converted institution's securities, (2) cumulative voting for directors, and (3) shareholders' ability to call special meetings relating to a change in the control of the institution or in its charter amendments.(12 C.F.R. $\S \S 563 b .3(i) 7,552.4(b)(8)(1986))$. This 
five-year limitation on ownership is even more stringent than the three-year limitation because it prohibits acquisition of more than $10 \%$ of equity without regard to regulatory approval.

Congress's reason for these ownership restrictions was twofold. First, it sought to persuade the managers of mutual thrifts to support conversion to stock organizations.

Because managers of a mutual thrift control the firm's assets free of direction by depositors, who are the legal owners of the firm, these managers enjoy a virtual lifetime compensation contract. They can engage in perquisite consumption that reduces firm value as long as their actions are not so brazen

as to instigate a run by depositors. ${ }^{5}$ By protecting these managers from the market for corporate control during the three to five years following conversion, Congress sought to encourage them to support proposed conversions. Recognizing that the five-year protection period might not be sufficient to induce some managers to support conversion, the FHLBB in its November 1986 amendments to the Conversion Regulation sought to reduce the thrift managers' uncertainty by emphasizing and justifying the use of employee stock ownership plans as a way to reduce exposure to unwanted takeovers (see Williams, Fleck, and Comizio (1987, p. 271)).

Congress also was concerned about the potential for managerial abuses of inside information. The initial stockholders of a converted thrift gain ownership of assets in place as well as their initial investment. Therefore, they receive a wealth transfer from the former depositors, who previously owned assets in place, unless those depositors purchase equity in

5 The relative expense preferences of mutual firms and stock firms have been studied extensively. See, for example, Masulis (1987) or Mester (1991). 
proportion to their share of deposits. Fearing that managers of mutual thrifts would use their inside information about the true value of assets in place to effect wealth transfers from depositors by acquiring large blocks of stock at bargain basement prices, Congress limited managers, as well as other parties, to a $10 \%$ share in the converted firm. ${ }^{6}$ With the restrictions on ownership, the Rule effectively insulates converted institutions from takeovers for up to five years. Thus, during this period, firms with superior management are prevented from acquiring firms with inefficient management and, thereby, from creating value for shareholders in the target firm. ${ }^{7}$

The Rule also weakens managers' incentives to create value for shareholders. Jensen and Murphy (1990) argue that these incentives depend on the fraction of the firm's equity held by managers. The Rule's $10 \%$ limit on managerial equity investment in the firm is

6 Williams, Fleck, and Comizio (1987) discuss in detail the evolution of the FHLBB's Conversion Regulation, including concerns that motivated the adoption of the antitakeover provisions.

7 In one case, First Federal of Alabama, FSB in December 1989 filed suit in U.S. District Court to prohibit First Federal Acquisition Corporation from proceeding with a tender offer to purchase in more than $10 \%$ of the thrift's outstanding shares. In January 1990, Judge U. W. Clemson placed an injunction on the tender offer and enjoined the prospective acquirer from making any further tender offers to purchase more than $10 \%$ of the thrift's stock, citing the thrift's charter provisions prohibiting any person from acquiring more than $10 \%$ of the thrift's stock during the first five years following its conversion from mutual to stock organization in December 1986. In March 1990, the Eleventh District Court of Appeals affirmed Judge Clemson's decision. First Federal Acquisition Corporation then dropped its takeover effort. In another case, reported in the December 9, 1984, issue of the American Banker, the FHLBB fined officers of Hawkeye Bancorp. of Des Moines more than $\$ 1$ million for violating the anti-takeover rule by acquiring stock in four North Carolina thrifts in excess of the $10 \%$ limit. 
significantly lower than the average ownership by all officers and directors reported for nonregulated industries (e.g., Mehran, 1992 and McConnell and Servaes, 1990).

By limiting ownership, the Rule also restricts equity-based managerial compensation, thus weakening the link between pay and performance. For example, although stock options may be granted to managers at the time of conversion (subject to later shareholder approval), a manager may hold no more than $10 \%$ of the thrift's outstanding stock after conversion. (See Williams, Fleck, and Comizio (1987, p. 280)). Thus, the sum of a manager's direct equity ownership and potential ownership in the form equity-based compensation is also limited to $10 \%$ for a period of three to five years after conversion. A maximum equity investment of $10 \%$ may not be large enough to motivate managers to make value-maximizing decisions, however. In fact, the limitation's effects may be felt even longer, as managers may take additional years to increase their percentage ownership share of the firm significantly.

The $10 \%$ ownership restrictions can also constrain a firm's financial policies. For example, a thrift's repurchase of its own stock that would increase a manager's ownership above $10 \%$, or a thrift's issue of convertible debt that in the event of conversion would push the lender above $10 \%$ ownership of the firm's equity, would be a violation of the Rule. ${ }^{8}$

To summarize, the Post-Conversion Anti-takeover Rule can affect the performance of a converted thrift institution by limiting ownership by insiders and outside blockholders. By restricting insider ownership, the Rule weakens the link between effort and reward. This

8 In general, converted institutions are not permitted to purchase their own stock for a period of three years after conversion except under special situations that also require regulatory approval. See Williams (1994, pp. 7-39) for discussion of these special situations. 
suggests that managerial ownership should increase, and firm performance should improve, after the ownership limitations expire. By restricting outside block ownership, the Rule also weakens the disciplinary role of the market for corporate control, thus entrenching managers. This suggests that outside block ownership should increase, and firm performance should improve, after limitations expire. In this study, we examine whether expiration of the Rule does in fact lead to increased firm ownership by insiders and by outside blockholders and whether any such increases are linked to improved performance.

\section{Data and Methodology}

Our analysis is based on the performance and ownership characteristics of 88 FSLICinsured thrift institutions that converted from mutual to stock ownership during 1983-87 and that following conversion were publicly traded on the New York Stock Exchange, or the American Stock Exchange, or in the over-the-counter market for at least seven years. The firms were identified by cross-referencing a list of mutual thrifts that filed applications for conversion with the FHLBB during 1983-87 against a list of publicly traded thrifts compiled by SNL Securities of Charlottesville, VA, and against the 1993 Center for Research in Security Prices (CRSP) database. FHLBB regulations required that all thrifts seeking to convert from mutual to stock ownership file an application with and obtain the approval of the FHLBB prior to conversion. Status as a publicly-traded thrift an active thrift subsidiary as of year-end 1993 was confirmed using information from the Bloomberg Financial News Network. 
$-11-$

This procedure produced an initial sample of 96 firms. We eliminated five thrifts for which we were unable to obtain ownership data for at least one year in both the preexpiration and post-expiration periods. For the remaining 91 firms, we are able to construct market-based performance measures for each of the three years before and at least the first year after expiration of the anti-takeover provisions. ${ }^{9}$ To ensure that our results were not influenced by contaminating events, we analyzed these performance measures for outliers. Twelve firms had reported post-expiration annual returns in excess of $100 \%$. We investigated news reports about these firms appearing in the American Banker and identified three whose returns were clearly attributable to factors other than changes in ownership structure. ${ }^{10}$ We removed these three firms from the initial sample, leaving a final sample of 88 firms. As

9 Because year-end 1994 stock-price data were not available at the time of this study, we have only six years of return data for 1987 conversions and only seven years of return data for 1986 conversions.

10 Elmwood Federal Savings Bank announced in April 1993 that it was considering selling the company. In July 1993, Keystone Financial Corporation announced that it would acquire Elmwood, with the deal closing during the first quarter of 1994. Elmwood's stock price climbed from $\$ 10.50$ per share at the end of March 1993 to $\$ 22.25$ at the end of December 1993 , for a return of more than $110 \%$.

Central Holding Company, parent of Colonial Central Savings Bank, FSB, announced in October 1993 that it would be acquired by Standard Federal Bank for a purchase price of $\$ 5.50$ per share in cash, with closing scheduled for early 1994 . Central Holding, which had traded at less than one dollar per share as of year-end 1992, recorded a gain of more than $500 \%$ for calendar year 1993 .

First Citizens' Financial Corporation was trading at less than one dollar per share during 1991 when it announced that the Office of Thrift Supervision (OTS) had approved its recapitalization plan. Approval by OTS effectively removed the threat that the thrift would be placed into conservatorship by the Resolution Trust Corporation. Within a year of the recapitalization announcement, the thrift was trading at $\$ 5.00$ per share, for an annual stock return of more than $500 \%$. 
shown in table 1 , the 88 thrifts comprise $19 \%$ of the 473 thrifts that converted from mutual to stock ownership during 1983-87.

We define the pre-expiration measurement period, which we denote years $-3,-2$, and 1 in relation to expiration, as the three full calendar years preceding the expiration of the antitakeover provisions (see Fig. 1). Because conversion occurred during year -5 relative to expiration, this procedure excludes any stock-price effects associated with the firm's initial public offering. We define the post-expiration measurement period, which we denote years 1 , 2, and 3 in relation to expiration, as the first, second, and third full calendar years after expiration of the anti-takeover provisions. Excluded from both measurement periods is the calendar year during which the anti-takeover provisions expired. Therefore, the firm's ownership structure is restricted throughout our pre-expiration measurement periods, but unrestricted throughout our post-expiration measurement period. Moreover, this excludes any stock-price effects associated with expiration of the anti-takeover provisions in year 0 . We construct our annual performance measures using stock-price data obtained from CRSP for 1984-93.

Because we focus on conversions occurring during a small number of years, the performance of our sample firms in the pre- and post-expiration periods is likely to have been affected by changes in the thrift industry and the economy as a whole. In the late 1980s, the thrift industry suffered large losses as a result of lax underwriting practices coupled with declining commercial real estate prices. Associated with those losses were large declines in the share prices of thrifts. In the early 1990 s, share prices rose significantly as the commercial real estate market stabilized and the most financially troubled thrifts were sold or 
closed. As shown in table 2, the median stock returns for non-sample publicly traded thrifts were negative in $1986,1987,1989$, and 1990 , with a low of $-41.9 \%$ in 1990 , but were positive in 1985,1988 , and $1991-93$, with a high of $61.0 \%$ in 1992 . To control for influences that produced these wide swings in industry performance, for each sample thrift's performance measure we subtract the median annual return for a control group of non-sample publicly traded thrifts from the sample thrift's annual stock return (where annual returns are measured from year-end to year-end.)

We created our control group by combining a list of publicly traded thrifts obtained from SNL Securities with an analogous list obtained from the Office of Thrift Supervision and omitting the 96 converting thrifts in the initial sample. To control for differences in size and location, we omitted non-sample thrifts trading on the NYSE or AMEX, as most of our sample firms trade over the counter. ${ }^{11}$

Data on insider ownership came from firm proxy statements, data on institutional block ownership from schedule 13F filings compiled by CDA Technologies of Rockville, MD, and data on ESOP and noninstitutional block ownership from Schedule 13D and 13G filings. ${ }^{12}$ We construct separate measures for institutional and noninstitutional block

11 Clearly, adjusting for the wide differences in thrift industry returns observed at different times during the sample period is a key issue. Because we use the medianadjusted return as our performance measure, our results are robust with respect to selection of the control group of firms. Results are qualitatively unchanged when thrifts in the tails of the return distribution are omitted from the control group.

12 Schedule $13 \mathrm{~F}$ is filed with the SEC by institutional investors that manage more than $\$ 100$ million in assets, and schedules 13D and 13G are filed with the SEC or OTS (depending on with which agency the company files) by every stockholder (individual or corporation) that owns $5 \%$ or more of a publicly-held U.S. corporation. Schedule 13D also requires disclosure of the stockholder's intent, e.g., for purposes of 
ownership because the motivations of these two groups of blockholders may differ (e.g., Holderness and Sheehan, 1988, p. 323.)

\section{Results}

\subsection{Unadjusted stock returns}

Column 2 in panels A and B, table 3 shows unadjusted average stock returns for the sample firms. The mean for the pre-expiration period is $1.15 \%$, not significantly different from zero, whereas the mean for the post-expiration period is $40.87 \% .^{13}$ The 39.72 percentage point difference in performance between the two periods is statistically significant at the $1 \%$ level. These results should be viewed with caution, however, because they are heavily influenced by trends that influenced the performance of the thrift industry as a whole.

\subsection{Industry-adjusted stock returns}

Column 3 in panels $\mathrm{A}$ and $\mathrm{B}$, table 3 shows average industry-adjusted stock returns for years -3 to -1 and years 1 to 3 . The sample firms' performance exceeded that of the control group in both the pre-expiration and post-expiration periods and was better after the antitakeover provisions expired. The mean industry-adjusted return for the pre-expiration period is $8.69 \%$, significant at the $1 \%$ level, whereas the mean for the post-expiration period is

investment or for purposes of control.

13 The means for years $-3,-2$, and -1 and for years 1,2 , and 3 are calculated as the average of each firm's three-year means. 
$11.83 \%$, also significant at the $1 \%$ level. The 3.14 percentage point difference between the two periods, however, is not statistically different from zero.

\subsection{Abnormal industry-adjusted stock returns}

Healy, Palepu, and Ruback (1992) observe that the appropriate benchmark for postmerger performance depends on the relation, if any, between pre- and post-merger performance. Similar logic applies to the relation, if any, between the performance of the sample firms before and after expiration of the anti-takeover provisions. If there is no relation, the appropriate benchmark for measuring post-expiration performance is zero. If there is a relation, the appropriate benchmark is the pre-expiration industry-adjusted return.

To test whether firm performance improved following expiration of the anti-takeover provisions, we employ a variation of the methodology used by Healy, Palepu, and Ruback (1992), who examine post-acquisition performance of large industrial firms involved in mergers. The methodology incorporates the relation between the pre- and post-expiration industry-adjusted returns. We regress the post-expiration return against the pre-expiration return as follows:

$$
I A R_{\text {post-expiration, } i}=\alpha+\beta I A R_{\text {pre-expiration, } i}+\epsilon_{i}
$$

where $I A R_{\text {post-expiration, } i}$ is the mean annual industry-adjusted stock return for company $i$ during the post-expiration years (years 1,2 , and 3 ) and $I A R_{\text {pre-expiration, } i}$ is the mean for the preexpiration years (years $-3,-2$ and -1 ). The intercept term $\alpha$ is our industry-adjusted measure of excess performance. As Healy, Palepu, and Ruback (1992) point out, the slope coefficient $\beta$ measures the correlation between returns in the pre- and post-expiration periods, so that $\beta$ 
$I A R_{\text {pre-expiration, } i}$ measures the effect of pre-expiration performance on post-expiration performance. Hence, the intercept $\alpha$ is independent of pre-expiration returns. ${ }^{14}$

As shown in table 4 , the estimated intercept is $14.1 \%$, significant at the $1 \%$ level. This indicates that stock returns increased $14.1 \%$ per year during the three years following expiration of the anti-takeover provisions, after controlling for pre-expiration performance. This finding is strong evidence of significant improvement in performance following the removal of restrictions on firm ownership structure. ${ }^{15}$

The -0.27 estimate of $\beta$ is marginally significant ( $p$-value $=0.11$ ), indicating that industry-adjusted returns revert toward the mean. ${ }^{16}$ This result is consistent with that of DeBondt and Thaler (1985), who find that firms with large equity losses in one three-year period experience large positive excess returns in the next three year period. Even after adjustment for industrywide trends, our sample is characterized by firms that experienced large negative returns in the pre-expiration period followed by large positive returns in the

14 It is instructive to note that by imposing the restriction that $(\beta=1)$, eq. (1) can be transformed into

$$
\Delta I A R_{i}=\alpha+\epsilon_{i},
$$

where $\triangle I A R_{i}$ is the change in industry-adjusted performance from the pre-expiration to the post-expiration period. Here, $\alpha$ is equivalent to the difference in performance from the pre- to the post-expiration period appearing at the bottom of table 3 . We can reject this restriction at standard significance levels.

15 To control for potential differences in firms that converted in different years, we reestimated eq. (1) including dummy variables for each firm's year of conversion. None of these dummy variables even approached standard levels of statistical significance.

${ }^{16}$ Healy, Palepu, and Ruback (1992) report a positive and significant estimate of $\beta$, but they model accounting cash flows whereas we model market-value stock returns. 
post-expiration period. One explanation for such return behavior is that the thrifts with the most severe agency problems perform worse in the pre-expiration period and best in the postexpiration period.

\subsection{Changes in firm ownership structure}

We evaluate four measures of changes in insider and outsider ownership from the preexpiration to the post-expiration period:

1) the largest percentage ownership by a single officer or director, ${ }^{17}$

2) the largest percentage ownership by a single institutional blockholder,

3) the largest percentage ownership by a single noninstitutional blockholder, and

4) the percentage ownership by the firm's employee stock ownership plan.

As with the performance data, we obtain firm-specific values for each measure in the three years before and after expiration of the anti-takeover provisions. We test for differences in pre- and post-expiration ownership structure using the $t$-statistic:

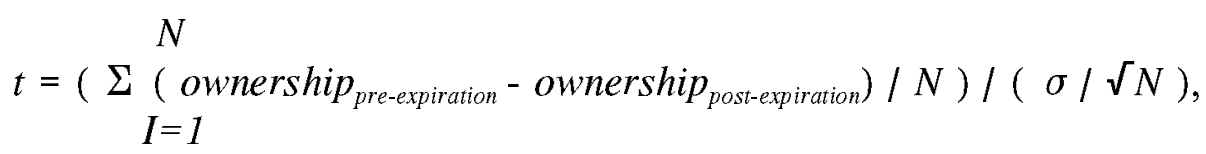

where ownership pre-expiration is the average percentage ownership in the pre-expiration period and ownership post-expiration is the average percentage ownership in the post-expiration period, $\sigma$ is the standard deviation of the distribution of the change in ownership, and $N$ is the number

17 In most cases, either the chief executive officer or the chairman of the board of directors held the largest percentage ownership by any single officer or director. The percentage ownership includes stock options that can be exercised within 60 days. 
of converting thrifts. Average ownership percentages in the pre- and post-expiration periods are calculated by averaging across firms the three-year period mean for each firm.

In interpreting the results, it is important to remember that the $10 \%$ limitation on ownership applies to "any group of persons acting in concert." This language means that the constraint can be binding even when the largest reported percentage ownership by a single investor is less than $10 \%$, and that the combined ownership by all insiders or institutional investors can exceed $10 \%$ without imposing a binding constraint as long as the FHLBB does not consider the group to be acting in concert. In practice, the ultimate decision about whether a group of investors are constrained by the $10 \%$ limitation rests with the courts.

Table 5 presents descriptive statistics on the largest percentage ownership by a single officer or director. In columns 2 through 5 are the total number of firms, the number of firms where insiders owned at least some stock, and the minimum and maximum ownership percentages. Comparison of columns 2 and 3 reveals that insider ownership was positive for all firms in each period except year -3 . Column 5 shows that the maximum ownership percentage in each of the three pre-expiration years was $10 \%$, indicating that the anti-takeover rule's constraint was binding for at least one firm in each year; further analysis of the data for individual firms reveals that the largest percentage ownership by an insider was more than $9 \%$ in at least one of the three pre-expiration years for five different firms.

Column 6 gives averages by year as well as $t$-statistics for the differences in the preand post-expiration period means. The annual pre-expiration means range from $2.97 \%$ to $3.71 \%$ with a three-year average of $3.32 \%$, whereas the annual post-expiration means range from $5.36 \%$ to $5.99 \%$ with a three-year average of $5.52 \%$. The $t$-statistic for the 2.20 
percentage point difference between the period means is 3.28 , significant at the $1 \%$ level. The bulk of this difference arises from year -1 to year +1 , when the mean percentage ownership by the largest insider increases from $3.71 \%$ to $5.36 \%$. This 1.65 percentage point difference is significant at the $5 \%$ level.

Earlier studies show that CEO compensation in the thrift industry (Cole and Mehran, 1991) and the banking industry (Houston and James, 1993) relies less on stock options than it does in other industries. Therefore, we speculate that most of the increase in ownership by insiders resulted from their direct purchase of their firm's stock through dealers or brokers rather than from accumulation of shares through the exercise of stock options.

Table 6 presents descriptive statistics on the largest percentage ownership by a single noninstitutional blockholder (a noninstitutional blockholder is a noninstitutional outside investor holding at least $5 \%$ of the firm). Comparisons of columns 2 and 3 reveal that the largest noninstitutional ownership was positive in each year for only about half of the firms. The maximums (reported in column 5) for the pre-expiration years exceed the $10 \%$ limit set by the 
anti-takeover rule, but for only two of the sample firms. ${ }^{18}$ Of the remaining 86 firms, 23 reported that the largest noninstitutional blockholder owned more than $9 \%$ of the firm in at least one of the three pre-expiration years.

The pre-expiration means for the largest percentage ownership by a noninstitutional blockholder range from $2.40 \%$ to $4.37 \%$ with a three-year average of $3.71 \%$, whereas the post-expiration means range from $4.54 \%$ to $5.24 \%$ with a three-year average of $4.68 \%$ (column 6). The $t$-statistic for the 0.97 percentage point difference between the period means is 1.58 ( $p$-value $=0.12)$.

Table 7 presents descriptive statistics on the largest percentage ownership by a single institutional investor. Comparisons of columns 2 and 3 reveal that institutional investors held shares in most, but not all, firms in each year. The $10 \%$ maximums in the fifth column of table 7 indicate that the anti-takeover rule's constraint on ownership was binding in each of the three pre-expiration periods for at least one firm. ${ }^{19}$ Analysis of data for individual firms

\footnotetext{
18 United Savings Bank of Montana reported that a noninstitutional blockholder, First Montana Title Insurance Company, owned more than $10 \%$ of its stock in each of the three pre-expiration years. According to a company spokesperson, United Savings Bank did not adopt the optional five-year charter protection, which is more restrictive than the standard three-year regulatory protection (see discussion on pp. 4-9), and the blockholder had obtained prior written approval from the FHLBB to exceed the $10 \%$ regulatory maximum. Palfed Inc. of South Carolina, reported that a partnership led by Weldon Wyatt had acquired 20.70\% of its stock in 1989 (year -1). Palfed sued Mr. Wyatt, and in a subsequent settlement Mr. Wyatt agreed to sell his shares.

19 Chester Valley Bancorp of Pennsylvania, reported that an institutional blockholder, Meridian Bancorp Inc., owned in excess of $10 \%$ of its stock in year -1 . Closer review reveals that Meridian's ownership was unchanged from year -2 to -1 at 115,000 shares, but that Chester Valley engaged in a stock repurchase of 208,000 shares during year 1, pushing Meridian's ownership share to $12.2 \%$. Apparently, this violation was not noticed or challenged by other shareholders, management, or regulators.
} 
shows that for 20 firms, the largest percentage ownership by an institutional investor was more than $9 \%$ in at least one of the three pre-expiration years.

The pre-expiration means for the largest percentage ownership by an institutional investor (shown in column 6) range from $4.48 \%$ to $4.69 \%$, with a three-year average of $4.59 \%$, whereas the post-expiration means range from $4.36 \%$ to $4.75 \%$, with a three-year average of $4.85 \%$. The 0.26 percentage point difference between the period means is not significantly different from zero.

Table 8 presents descriptive statistics on the percentage ownership by the firm's employee stock ownership plan when that percentage was greater than $5 \%{ }^{20}$ Comparison of columns 2 and 3 reveals that in only a small fraction of the sample firms rine firms in the pre-expiration period and 13 in the post-expiration period-tid ESOPs own more than $5 \%$ of the firm's equity. Consequently, the average ownership percentages for the entire sample are quite small. The pre-expiration means for percentage ownership by ESOPs range from $0.53 \%$ to $0.79 \%$, with a three-year average of $0.60 \%$, whereas the post-expiration means range from $1.04 \%$ to $1.57 \%$, with a three-year average of $1.23 \%$ (column 6 ). The $t$-statistic for the 0.63 percentage point difference between the period means is 3.04 , significant at the $1 \%$ level.

Although the percentages of shares held by these ESOPs do not appear large enough to deter a takeover threat, these percentages are biased downward (see note 21). Moreover, these are the percentages actually allocated to leveraged ESOPs rather than the percentages

20 ESOPs with investments of less than 5\% do not have to file the $13 \mathrm{D}$ and $13 \mathrm{G}$ schedules from which we obtained our ESOP ownership data. 
allowed under the adopted plans. ${ }^{21}$ These thrifts could use a previously established ESOP to secure loans to purchase additional employer stock in an effort to defeat a tender offer. ${ }^{22}$

In summary, we find significant changes in firm ownership structure following expiration of the anti-takeover provisions. Ownership by insiders, by noninstitutional outside blockholders, by institutional blockholders, and by ESOPs increased, and these increases were statistically significant for insiders and ESOPs.

\subsection{The effect of changes in ownership on firm performance.}

In Sections 4.3 and 4.4, we establish that firm performance improves, and that ownership by insiders and outside blockholders increases, after the anti-takeover provisions expire. Although these findings are consistent with the theory that increases in insider ownership and outside blockholder ownership have positive influences on firm performance, they provide only indirect evidence. In this section, we expand the model of excess industryadjusted stock returns to provide more direct evidence. Specifically, we augment eq. (1) with an additional regressor measuring the percentage-point change in ownership by the largest insider from the pre-expiration to the post-expiration period, as follows:

$$
I A R_{\text {post-expiration, } i}=\alpha+\beta_{1} I A R_{\text {pre-expiration, } i}+\beta_{2} \Delta \text { largest insider ownership } i+\epsilon_{i},
$$

21 In the case of a leveraged ESOP, a firm may purchase shares for the ESOP with borrowed funds. The shares are allocated to the ESOP only as the debt is retired.

22 The IRS could argue, however, that neither the loan nor the subsequent purchases of employer stock was for the exclusive benefit of ESOP participants and beneficiaries, so that the ESOP trust would lose its tax qualification, rendering any contributions to the ESOP nondeductible and rendering earnings of the trust taxable. 
where $I A R_{\text {post-expiration, } i}$ and $I A R_{\text {pre-expiration, } i}$ are the median annual industry-adjusted stock returns in the pre- and post-expiration period for firm $I$, and $\Delta$ largest insider ownership $p_{i}$ is the percentage-point change in ownership by the officer or director with the largest shareholdings. ${ }^{23}$

We similarly expand the model of excess industry-adjusted stock returns in an effort to provide evidence about the relation between changes in outside blockholder ownership and firm performance. We augment eq. (1) with one of two additional regressors measuring the percentage point change in outside blockholder ownership from the pre-expiration to the postexpiration period, as follows:

$$
\begin{gathered}
I A R_{\text {post-expiration, } i}=\alpha+\beta_{1} I A R_{\text {pre-expiration, } i}+\beta_{2} \Delta \text { largest noninstitutional ownership } p_{i}+\epsilon_{i} \\
\text { and } \\
I A R_{\text {post-expiration, } i}=\alpha+\beta_{1} I A R_{\text {pre-expiration, } i}+\beta_{2} \Delta \text { largest institutional ownership } p_{i}+\epsilon_{i},
\end{gathered}
$$

where $I A R_{\text {post-expiration, } i}$ and $I A R_{\text {pre-expiration, } i}$ are the median annual industry-adjusted stock returns in the pre- and post-expiration periods for firm $i, \Delta$ largest non-institutional ownership $p_{i}$ is a dummy variable indicating an increase in ownership by the noninstitutional investor with the largest shareholdings, and $\Delta$ largest institutional ownership $p_{i}$ is the percentage point change in ownership by the institutional investor with the largest ownership. We use a dummy variable to measure changes in ownership by noninstitutional blockholders because these blockholders as well as ESOPs are identified in Schedule 13D and 13F filings only when

23 In calculating the percentage point change in ownership, the insider with the largest percentage ownership in the pre-expiration period need not be the same as the insider with the largest percentage ownership in the post-expiration period. Percentage point changes in ownership by institutional and noninstitutional blockholders are calculated in an analogous manner. 
they own at least $5 \%$ of the firm's shares. This censoring below 5\% introduces a nonlinearity into the observed ownership percentage for these two groups of shareholders.

In Section 4.3, we demonstrated that ESOP ownership increased in the post-expiration period. To provide evidence on the relation between ESOP ownership and firm performance, we augment eq. (1) with an additional regressor measuring the change in ESOP ownership from the pre-expiration to the post-expiration period, as follows:

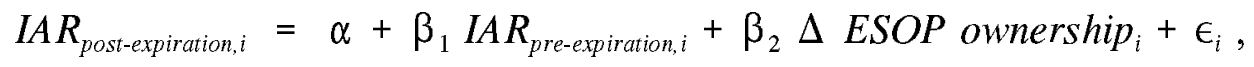

where $I A R_{\text {post-expiration, } i}$ and $I A R_{\text {pre-expiration, } i}$ are the median annual industry-adjusted stock returns

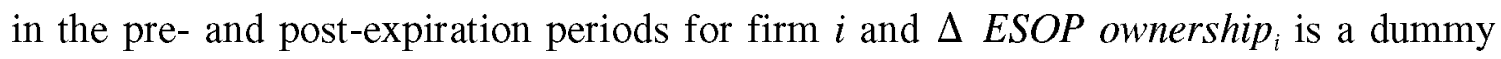
variable indicating an increase in ownership by the firm's employee stock ownership plan. Again, we use a dummy variable to measure ownership because of the limited information available from Schedules $13 \mathrm{D}$ and $13 \mathrm{~F}$.

In all cases, the percentage point changes in ownership are calculated as the mean percentage ownership during the post-expiration years (years 1, 2, and 3) less the mean percentage ownership during the pre-expiration years (years $-3,-2$, and -1 ). The dummy variables for positive changes in ownership are equal to 1 when the percentage point change in ownership is positive and zero otherwise. ${ }^{24}$

${ }^{24}$ It is instructive to note that by imposing the restriction that $\left(\beta_{1}=1\right)$, eqs. (2) through (5) can be transformed into

$$
\Delta \text { IAR }_{i}=\alpha+\beta_{2} \Delta \text { ownership }_{i}+\epsilon_{i},
$$

where $\triangle I A R_{i}$ is the change in industry adjusted performance from the pre-expiration to the post-expiration period. We can reject this restriction at standard significance 
Estimation of eq. (2) (panel A, table 9) gives a coefficient for $\Delta$ largest insider ownership $_{i}$ of 1.23 , which is statistically significant at the $5 \%$ level $(p$-value $=0.016)$. This result indicates that, on average, sample firms earned an extra $1.23 \%$ per year during the postexpiration period for each percentage point increase in ownership by the officer or director with the largest shareholdings. Thus, there is a positive correlation between post-expiration performance and changes in insider ownership.

Estimation of eq. (3) (panel B, table 9) indicates that sample firms earned an extra $14.5 \%$ per year during the post-expiration period when there was an increase in ownership by the largest noninstitutional investor (coefficient significant at the 5\% level, $p$-value $=0.028$ )

Estimation of eq. (4) (panel C, table 9) indicates that the coefficient for $\Delta$ largest institutional ownership $p_{i,} 0.79$, is not statistically different from zero. Thus, we are unable to demonstrate any effect on firm performance from changes in institutional blockholder ownership..$^{25}$

Together, the results in panels $\mathrm{B}$ and $\mathrm{C}$ of table 9 provide evidence, in support of Holderness and Sheehan (1988), that the identify of large blockholders is important to the functioning of the market for corporate control because the roles, and possibly the motivations, of institutional and noninstitutional blockholders differ. We speculate that the institutional blockholders, who by definition manage more than $\$ 100$ million is assets, held

levels for each specification. Results obtained while imposing this restriction, however, are not qualititively different from those presented here.

25 One might argue that blockholders other than the largest monitor management. To investigate, we also estimated eq. (3) using the percentage ownership by all institutional blockholders in place of the largest institutional ownership percentage. Results were not qualitatively different. 
shares of our sample thrifts solely for investment purposes, whereas the noninstitutional blockholders held shares not only for investment purposes but also for control purposes. Indeed, a review of the blockholders' reasons for filing reveals no case in which institutions filed for purposes of control, but numerous cases in which noninstitutional blockholders did so. Moreover, newly converted thrifts are, for the most part, small-capitalization stocks with market values in the $\$ 5$ million to $\$ 50$ million range that trade infrequently. It is costly for institutional investors to monitor such small firms, so they are likely to act only as passive investors. This is an interesting issue, one that we leave for future research.

Finally, estimation of eq. (5) (panel D, table 9) produces a coefficient for $\Delta$ ESOP ownership $_{i}$ of -15.7 (marginally significant, $p$-value $=0.11$ ), indicating that during the post-expiration period the annual return of sample firms was $15.7 \%$ less per year when ownership by the firm's ESOP increased. This finding at least suggests that ESOPs were adopted by sample firms as an impediment to potential acquirers, weakening the market for corporate control and is consistent with that of Gordon and Pound (1990), who document a negative stock market reaction when an ESOP is adopted in the presence of takeover activity.

\section{Summary and Conclusions}

In this study, we investigate whether regulatory restrictions on the ownership of public companies harm performance by preventing firms from choosing the best ownership structure. Using data for a sample of thrift institutions that converted from a mutual to a stock form of organization, we examine stock-price performance and ownership structure before and after 
the expiration of regulatory anti-takeover provisions that limit the percentage of a firm's stock that may be owned by an inside or outside investor.

These anti-takeover provisions, which were put in place to induce the managers of mutual thrifts to convert to stock ownership, create a natural laboratory for testing the impact of regulatory restrictions on ownership structure and the market for corporate control. The anti-takeover rule discussed here typifies a pattern of legislative and regulatory interference in capital markets (see Roe, 1990). Regulations often have subtle and unintended effects that in some cases turn out to be of first-order importance.

We find that after the anti-takeover provisions expire, insider ownership increases and firm performance improves significantly. Moreover, we link increases in insider ownership to improvement in firm performance. We also find that percentage ownership by noninstitutional outside blockholders increases following expiration of the anti-takeover provisions, and link these increases to improvement in firm performance. By constraining insider ownership, the anti-takeover rule weakens the link between reward and performance (Jensen and Murphy, 1990). By constraining outsider ownership, the rule also weakens the disciplinary role of the market for corporate control, thus entrenching managers (Jensen and Ruback, 1983). Although our findings do not resolve debate over whether the net economic effect of the anti-takeover provisions is positive or negative, they do provide evidence that the provisions interfere with the firm's ownership structure and, in turn, firm performance.

In contrast to our findings for noninstitutional blockholders, we find neither significant changes in percentage ownership by institutional blockholders nor a significant relation between changes in percentage ownership by institutional investors and firm performance. 
These results support the findings of Holderness and Sheehan (1988), who argue that the identify of large blockholders is important to the market for corporate control because their motivations may differ. One explanation for the lack of correlation between institutional ownership and firm performance is that institutional investors specialize in risk-sharing, and are unlikely to have a comparative advantage in monitoring management (e.g., Plosser, 1993). ${ }^{26}$ We suggest a different explanation for our findings that institutional blockholders are passive investors whereas noninstitutional blockholders often invest for the purpose of gaining control. We leave this hypothesis for future research.

Finally, we find significant changes in percentage ownership by ESOPs following expiration of the antitakeover provisions and a negative relation between such ownership changes and changes in firm performance. This relationship, though only marginally significant, is consistent with the hypothesis that firms adopted ESOP plans as a means of impeding the market for corporate control.

26 Others (e.g., Demsetz, 1993) argue that individual investors seldom own enough equity to allow shareholders the optimal degree of control over management. 


\section{References}

Cole, Rebel A. and Hamid Mehran, 1991, Executive compensation and corporate performance:

Evidence from thrift institutions, in: Rebuilding Banking: Proceedings of the 27th Annual Conference on Bank Structure and Performance (Federal Reserve Bank of Chicago), 227-247.

Cornett, Marcia Millon and Hassan Tehranian, 1992, Changes in corporate performance associated with bank acquisitions, Journal of Financial Economics 31, 211-234.

Crawford, J. Anthony, John R. Ezzell, and James A. Miles, 1995, Bank CEO pay-performance relations and the effects of deregulation, Journal of Business 68, 231-256.

DeBondt, Werner F. M. and Richard H. Thaler, 1985, Does the stock market over-react? Journal of Finance 40, 793-805.

Demsetz, Harold, 1983, The structure of ownership and the theory of the firm, Journal of Law and Economics 26, 375-390.

Demsetz, Harold, 1993, Financial regulation and the competitiveness of the large U.S. corporation, Economic Review (Federal Reserve Bank of St. Louis), 61-67.

Esty, Benjamin C, 1993, Ownership concentration and risk-taking in the S\&L industry, Harvard Business School mimeo.

Fama, Eugene F. and Michael C. Jensen, 1983, Separation of ownership and control, Journal of Law and Economics 26, 301-325.

Gordon, Lili A. and John Pound, ESOPs and corporate control, Journal of Financial Economics 27, 525-556

Healy, Paul M., Krishna M. Palepu, and Richard S. Ruback, 1992, Does corporate performance improve after mergers? Journal of Financial Economics 31, 135-175.

Hermalin, Benjamin E. and Nancy E. Wallace, 1994, The determinants of efficiency and solvency in savings and loans, Rand Journal of Economics 25, 361-381.

Holderness, Clifford G. and Dennis P. Sheehan, The role of majority shareholders in publicly held corporations: An exploratory analysis, Journal of Financial Economics 20, 317-346.

Houston, Joel and Christopher James, 1993, Managerial compensation, turnover, and risk-taking in banking, Working paper (University of Florida, Gainesville, FL).

Hubbard, R. Glenn and Darius Palia, 1995, Executive pay and performance: Evidence from the U.S. banking industry, Journal of Financial Economics 39, 105-130.

Jensen, Michael C. and William H. Meckling, 1976, Theory of the firm: Managerial behavior, agency costs and ownership structure, Journal of Financial Economics 3, 305-360. 
Jensen, Michael C. and Richard S. Ruback, 1983, The market for corporate control, Journal of Financial Economics 11, 5-50.

Jensen, Michael C. and Kevin J. Murphy, 1990, CEO incentives - It's not how much you pay, but how, Journal of Applied Corporate Finance, 36-49.

Jensen, Michael C. and Jerold B. Warner, 1988, The distribution of power among corporate mangers, shareholders, and directors, Journal of Financial Economics 20, 3-24.

Kane, Edward J., 1983, The role of government in the thrift industry's net worth crisis, in George Benston, ed., Financial Services: The Changing Institutions and Government Policy (Prentice-Hall, Inc., Engelewood Cliffs, NJ), 156-184.

Kane, Edward J. 1995, Three paradigms for the role of capitalization requirements in insured financial institutions, Journal of Banking and Finance 19, 431-459.

Masulis, Ronald, 1987, Changes in ownership structure: Conversions of mutual savings and loans to stock charter, Journal of Financial Economics 18, 29-60.

Mester, Loretta J., 1991, Agency costs among savings and loans, Journal of Financial Intermediation 1, 257-278.

McConnell, John J. and Henri Servaes, 1990, Additional evidence on equity ownership and corporate value, Journal of Financial Economics 27, 595-612.

Mehran, Hamid, 1992, Executive incentive plans, corporate control, and capital structure, Journal of Financial and Quantitative Analysis 27, 539-560.

Mehran, Hamid, 1995, Executive compensation structure, ownership, and firm performance, Journal of Financial Economics 38, 163-184.

Plosser, Charles J., 1993, Commentary, Economic Review (Federal Reserve Bank of St. Louis), 68-70.

Roe, Mark J., 1990, Political and legal restraints on ownership and control of public companies, Journal of Financial Economics 27, 7-41.

Williams, Julie L., 1994, Savings institutions: Mergers, acquisitions, and conversions (Law Journal Seminars-Press, New York, NY).

Williams, Julie L., J. Larry Fleck, and V. Gerard Comizio, 1987, Mutual-to-stock conversions: New capitalization opportunities and post-conversion control developments, Legal Bulletin (U.S. League of Savings Institutions) 53, 237-317. 
Table 1

Conversions by thrift institutions from mutual to stock ownership

The total number of converting thrifts is the number of thrift conversions approved by the Federal Home Loan Bank Board during each year. The number of converting thrifts in the sample is the number of thrifts identified by SNL Securities as being traded on the New York Stock Exchange, the American Stock Exchange, or the over-the-counter market, in each of the seven years following conversion.

\begin{tabular}{llll}
\hline Year & $\begin{array}{l}\text { Total number } \\
\text { of } \\
\text { converting thrifts }\end{array}$ & $\begin{array}{l}\text { Number of } \\
\text { converting thrifts } \\
\text { in sample }\end{array}$ & $\begin{array}{l}\text { Sample } \\
\text { as a percentage } \\
\text { of total }\end{array}$ \\
\hline 1983 & 83 & 11 & $13 \%$ \\
1984 & 96 & 13 & $14 \%$ \\
1985 & 78 & 11 & $14 \%$ \\
1986 & 86 & 24 & $28 \%$ \\
1987 & 130 & 29 & $22 \%$ \\
\hline $1983-87$ & 473 & 88 & $19 \%$ \\
\hline
\end{tabular}


Table 2

Median annual stock returns for non-sample, control group of OTC-traded thrift institutions, 1985-93.

Control group was created from a group of OTC-traded thrifts identified by combining a list obtained from SNL Securities with a list obtained from the Office of Thrift Supervision. Stock return data are taken from CRSP. The control group excludes all thrifts converting from mutual to stock during 1983-87.

\begin{tabular}{lll}
\hline Year & $\begin{array}{l}\text { Number } \\
\text { of firms }\end{array}$ & $\begin{array}{l}\text { Control group } \\
\text { median stock return }\end{array}$ \\
\hline 1985 & 127 & $40.8 \%$ \\
1986 & 142 & $-4.9 \%$ \\
1987 & 230 & $-21.8 \%$ \\
1988 & 253 & $6.5 \%$ \\
1989 & 259 & $-11.7 \%$ \\
1990 & 227 & $-41.9 \%$ \\
1991 & 206 & $39.6 \%$ \\
1992 & 188 & $61.0 \%$ \\
1993 & 129 & $28.3 \%$ \\
\hline
\end{tabular}


Table 3

Average annual stock returns for publicly traded thrifts for the three years preceding and the three years following the expiration of regulatory restrictions on firm ownership structure

These restrictions limit ownership by any person or group of persons acting in concert to $10 \%$ of the firm's outstanding shares during the five years following conversion from mutual to stock organization.

\begin{tabular}{|c|c|c|c|c|}
\hline $\begin{array}{l}\text { Years relative to } \\
\text { expiration of } \\
\text { restrictions on } \\
\text { ownership structure }\end{array}$ & $\begin{array}{l}\text { Mean } \\
\text { unadjusted } \\
\text { return }\end{array}$ & $\begin{array}{l}\text { Mean } \\
\text { industry- } \\
\text { adjusted } \\
\text { return }{ }^{\text {a }}\end{array}$ & $\begin{array}{l}\text { Percentage of } \\
\text { industry-adjusted } \\
\text { mean returns } \\
\text { that were positive }\end{array}$ & $\begin{array}{l}\text { Number } \\
\text { of } \\
\text { firms }\end{array}$ \\
\hline
\end{tabular}

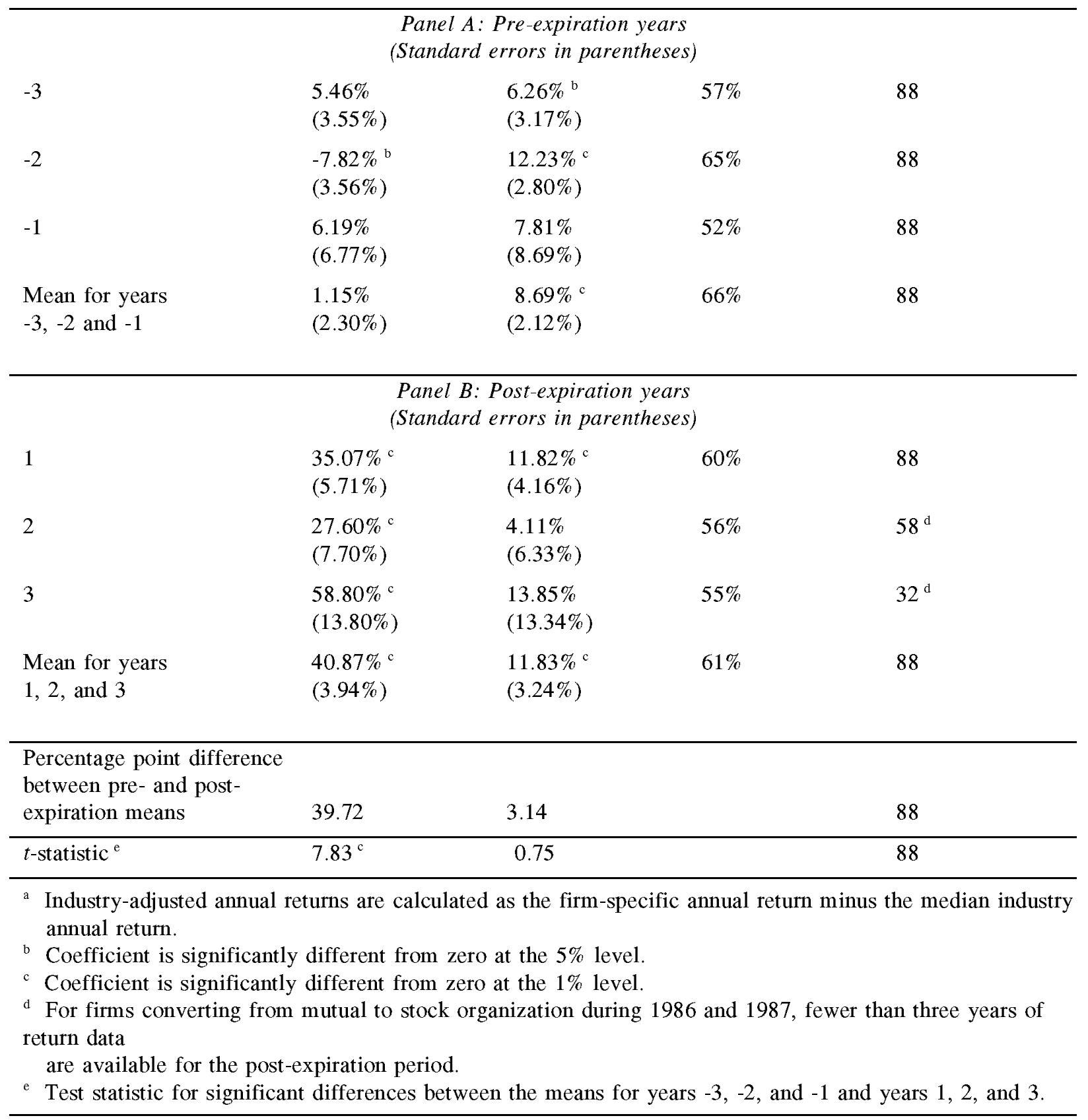


$-34-$ 
Table 4

Excess industry-adjusted stock returns of publicly traded thrifts for the three years preceding and the three years following the expiration of regulatory restrictions on firm ownership structure.

These restrictions limit ownership by any person or group of persons acting in concert to $10 \%$ of the firm's outstanding shares during the five years following conversion from mutual to stock organization. Industryadjusted returns are calculated as the firm-specific annual return less the median industry annual return.

$$
\begin{aligned}
& \text { (t-statistics in parentheses) } \\
& I A R_{\text {post-expiration, } i}=14.1 \%-0.27 \text { IAR }_{\text {pre-expiration, } i}^{(4.04)^{\mathrm{a}}} \quad(-1.64) \\
& R^{2}=0.030 \quad F \text {-statistic }=2.69 \quad N=88
\end{aligned}
$$

$I A R_{\text {post-expiration, } i}$ is the mean annual industry-adjusted stock return for company $i$ during the post-expiration period (years 1, 2, and 3) and $I A R_{\text {pre-expiration, } i}$ is the mean for the pre-expiration period (years $-3,-2$, and -1 ). The intercept term is the industry-adjusted measure of excess performance.

a Coefficient is significantly different from zero at the $1.0 \%$ level. 
Table 5

Average ownership of publicly traded thrifts by the insiders with the largest shareholdings for the three years preceding and the three years following the expiration of regulatory restrictions on firm ownership structure.

These restrictions limit ownership by any person or group of persons acting in concert to $10 \%$ of the firm's outstanding shares during the five years following conversion from mutual to stock organization.

\begin{tabular}{|c|c|c|c|c|c|}
\hline \multirow{2}{*}{$\begin{array}{l}\text { Years } \\
\text { relative to } \\
\text { expiration of } \\
\text { limitations on } \\
\text { ownership structure }\end{array}$} & \multirow{2}{*}{$\begin{array}{l}\text { Number } \\
\text { of } \\
\text { firms }\end{array}$} & \multirow{2}{*}{$\begin{array}{l}\text { Number } \\
\text { where an } \\
\text { insider } \\
\text { owned } \\
\text { stock }\end{array}$} & \multicolumn{3}{|c|}{ Largest percentage shareholdings by an insider } \\
\hline & & & Minimum & Maximum & Mean \\
\hline \multicolumn{6}{|c|}{ Panel A: Pre-expiration years } \\
\hline-3 & $62^{\mathrm{a}}$ & 59 & $0.00 \%$ & $10.00 \%$ & $2.97 \%$ \\
\hline-2 & $76^{\mathrm{a}}$ & 76 & $0.20 \%$ & $10.00 \%$ & $3.58 \%$ \\
\hline-1 & 88 & 88 & $0.30 \%$ & $10.00 \%$ & $3.71 \%$ \\
\hline $\begin{array}{l}\text { Mean for years } \\
-3,-2 \text { and }-1\end{array}$ & 88 & 88 & $0.30 \%$ & $10.00 \%$ & $3.32 \%$ \\
\hline \multicolumn{6}{|c|}{ Panel B: Post-expiration years } \\
\hline 1 & 88 & 88 & $0.40 \%$ & $44.60 \%$ & $5.36 \%$ \\
\hline 2 & $58^{\mathrm{a}}$ & 58 & $0.40 \%$ & $44.60 \%$ & $5.99 \%$ \\
\hline 3 & $32^{a}$ & 32 & $0.40 \%$ & $44.60 \%$ & $5.93 \%$ \\
\hline $\begin{array}{l}\text { Mean for years } \\
1,2, \text { and } 3\end{array}$ & 88 & 88 & $0.40 \%$ & $44.60 \%$ & $5.52 \%$ \\
\hline $\begin{array}{l}\text { Percentage point difference } \\
\text { between pre- and post- } \\
\text { expiration means }\end{array}$ & 88 & 73 & & & 2.20 \\
\hline$t$-statistic ${ }^{b}$ & & & & & $3.28^{\mathrm{c}}$ \\
\hline $\begin{array}{l}\text { Percentage point difference } \\
\text { between years }-1 \text { and }+1 \\
t \text {-statistic }\end{array}$ & 88 & 65 & & & $\begin{array}{l}1.65 \\
2.38^{\mathrm{e}}\end{array}$ \\
\hline $\begin{array}{l}\text { For firms converting durin } \\
\text { are available either before } \\
\text { b Test statistic for significar } \\
\text { the mean for post-expirati } \\
\text { c Statistically significant di } \\
\text { d Test statistic for significar } \\
\text { e Statistically significant dif }\end{array}$ & $\begin{array}{l}1983,19 \\
\text { or after ex } \\
\text { differenc } \\
\text { n years } 1, \\
\text { ference at } \\
\text { differenc } \\
\text { erence at }\end{array}$ & $\begin{array}{l}1986 \text {, and } \\
\text { ation of the } \\
\text { between the } \\
\text { and } 3 \text {. } \\
1.0 \% \text { leve } \\
\text { between pr } \\
5.0 \% \text { level }\end{array}$ & $\begin{array}{l}\text { 37, fewer th } \\
\text { ti-takeover } \\
\text { ean for pre } \\
\text { piration ye }\end{array}$ & $\begin{array}{l}\text { e years of } \\
\text { ions. See fi } \\
\text { ion years }-3 \\
\text { ad post-expi }\end{array}$ & $\begin{array}{l}\text { hip data } \\
\text { nd }-1 \text { and } \\
\text { year } 1 .\end{array}$ \\
\hline
\end{tabular}


Table 6

Average ownership of publicly traded thrifts by the noninstitutional blockholders with the largest shareholdings for the three years preceding and the three years following the expiration of regulatory restrictions on firm ownership structure.

These restrictions limit ownership by any person or group of persons acting in concert to $10 \%$ of the firm's outstanding shares during the five years following conversion from mutual to stock organization.

\begin{tabular}{|c|c|c|c|c|c|}
\hline \multirow{2}{*}{$\begin{array}{l}\text { Years } \\
\text { relative to } \\
\text { expiration of } \\
\text { limitations on } \\
\text { ownership structure }\end{array}$} & \multirow{2}{*}{$\begin{array}{l}\text { Number } \\
\text { of } \\
\text { firms }\end{array}$} & \multirow{2}{*}{$\begin{array}{l}\text { Number } \\
\text { where a } \\
\text { noninstitutiona } \\
1 \\
\text { blockholder } \\
\text { owned stock }\end{array}$} & \multicolumn{3}{|c|}{$\begin{array}{l}\text { Largest percentage shareholdings by a } \\
\text { noninstitutional blockholder }\end{array}$} \\
\hline & & & Minimum & Maximum & Mean \\
\hline \multicolumn{6}{|c|}{ Panel A: Pre-expiration years } \\
\hline-3 & $62^{\mathrm{a}}$ & 18 & $0.00 \%$ & $12.40 \%{ }^{\mathrm{b}}$ & $2.40 \%$ \\
\hline-2 & $76^{a}$ & 33 & $0.00 \%$ & $14.10 \%^{\mathrm{b}}$ & $3.62 \%$ \\
\hline-1 & 88 & 44 & $0.00 \%$ & $20.70 \%$ & $4.37 \%$ \\
\hline $\begin{array}{l}\text { Mean for years } \\
-3,-2 \text { and }-1\end{array}$ & 88 & 58 & $0.00 \%$ & $13.50 \%$ & $3.71 \%$ \\
\hline \multicolumn{6}{|c|}{ Panel B: Post-expiration years } \\
\hline 1 & 88 & 41 & $0.00 \%$ & $38.80 \%$ & $4.54 \%$ \\
\hline 2 & $58^{\mathrm{a}}$ & 30 & $0.00 \%$ & $41.00 \%$ & $5.24 \%$ \\
\hline 3 & $32^{\mathrm{a}}$ & 17 & $0.00 \%$ & $16.40 \%$ & $4.69 \%$ \\
\hline $\begin{array}{l}\text { Mean for years } \\
1,2 \text {, and } 3\end{array}$ & 88 & 49 & $0.00 \%$ & $39.90 \%$ & $4.68 \%$ \\
\hline $\begin{array}{l}\text { Percentage point difference } \\
\text { in pre- and post-expiration } \\
\text { means } \\
t \text {-statistic } \\
\text { c }\end{array}$ & 88 & 38 & & & $\begin{array}{l}0.97 \\
1.58\end{array}$ \\
\hline
\end{tabular}


a For firms converting during 1983, 1984, 1986, and 1987, fewer than three years of ownership data are available either before or after expiration of the anti-takeover provisions. See figure 1.

b One firm, United Savings Bank of Montana, reported that a noninstitutional blockholder, First Montana Title

Insurance Company, owned more than $10 \%$ of its stock in each of the three pre-expiration years.

According to

a company spokesperson, United Savings Bank did not adopt the optional five-year charter protection, which is

more restrictive than the standard three-year regulatory protection and the blockholder had obtained prior written approval from the FHLBB to exceed the 10\% regulatory maximum. A second firm, Palfed Inc. of South Carolina, reported that 7 Oaks, a partnership led by Weldon Wyatt, had acquired 20.70\% of its stock in 1989 (year 1).

Palfed sued Mr. Wyatt, and in a subsequent settlement Mr. Wyatt agreed to sell his shares.

c Test statistic for significant differences between the mean for pre-expiration years $-3,-2$, and -1 and the mean for post-expiration years 1,2 , and 3 .

${ }^{\mathrm{d}}$ Statistically significant difference at the $10.0 \%$ level.

Table 7

Average ownership of publicly traded thrifts by the institutional blockholders with the largest shareholdings for the three years preceding and the three years following the expiration of regulatory restrictions on firm ownership structure.

These restrictions limit ownership by any person or group of persons acting in concert to $10 \%$ of the firm's outstanding shares during the five years following conversion from mutual to stock organization.

\begin{tabular}{|c|c|c|c|c|c|}
\hline \multirow{2}{*}{$\begin{array}{l}\text { Years } \\
\text { relative to } \\
\text { expiration of } \\
\text { limitations on } \\
\text { ownership structure }\end{array}$} & \multirow{2}{*}{$\begin{array}{l}\text { Number } \\
\text { of } \\
\text { firms }\end{array}$} & \multirow{2}{*}{$\begin{array}{l}\text { Number } \\
\text { where an } \\
\text { institutional } \\
\text { blockholder } \\
\text { owned stock }\end{array}$} & \multicolumn{3}{|c|}{$\begin{array}{l}\text { Largest percentage shareholdings by an } \\
\text { institutional blockholder }\end{array}$} \\
\hline & & & Minimum & Maximum & Mean \\
\hline \multicolumn{6}{|c|}{ Panel A: Pre-expiration years } \\
\hline-3 & $62^{\mathrm{a}}$ & 53 & $0.00 \%$ & $10.00 \%$ & $4.48 \%$ \\
\hline-2 & $76^{\mathrm{a}}$ & 66 & $0.00 \%$ & $10.00 \%$ & $4.57 \%$ \\
\hline-1 & 88 & 73 & $0.00 \%$ & $12.20 \%^{\mathrm{b}}$ & $4.69 \%$ \\
\hline $\begin{array}{l}\text { Mean for years } \\
-3,-2 \text { and }-1\end{array}$ & 88 & 81 & $0.00 \%$ & $11.60 \%{ }^{b}$ & $4.59 \%$ \\
\hline
\end{tabular}


1

2

3

Mean for years

1,2 , and 3

Percentage point difference

between pre- and post-

expiration means

$t_{\text {-Statistic }}{ }^{c}$
88

$58^{\mathrm{a}}$

$32^{\text {a }}$

88

87

42

0.26

0.98

a For firms converting during 1983,1984, 1986, and 1987, fewer than three years of ownership data are available either before or after expiration of the antitakeover provisions. See figure 1.

b One firm, Chester Valley Bancorp of Pennsylvania, reported that an institutional blockholder, Meridian Bancorp

Inc., owned more than $10 \%$ of its stock in year -1 . Closer review reveals that Meridian's ownership was unchanged

from year -2 to -1 at 115,000 shares, but that Chester Valley engaged in a stock repurchase of 208,000 shares

during the year, pushing Meridian's ownership share to $12.2 \%$. This violation apparently was not noticed or

challenged by other shareholders, management, or regulators.

c Test statistic for significant differences between the mean for pre-expiration years $-3,-2$, and -1 and the mean for

post-expiration years 1,2 , and 3 . 
Table 8

Average ownership of publicly traded thrifts by employee stock ownership plans (ESOPs) for the three years preceding and the three years following the expiration of regulatory restrictions on firm ownership structure.

These restrictions limit ownership by the firm's ESOP to 25\% of the firm's outstanding shares during the five years following conversion from mutual to stock organization.

\begin{tabular}{|c|c|c|c|c|c|}
\hline \multirow{2}{*}{$\begin{array}{l}\text { Years } \\
\text { relative to } \\
\text { expiration of } \\
\text { limitations on } \\
\text { ownership structure }\end{array}$} & \multirow{2}{*}{$\begin{array}{l}\text { Number } \\
\text { of } \\
\text { firms }\end{array}$} & \multirow{2}{*}{$\begin{array}{l}\text { Number } \\
\text { where } \\
\text { the firm's } \\
\text { ESOP } \\
\text { owned stock }\end{array}$} & \multicolumn{3}{|c|}{$\begin{array}{l}\text { Percentage shareholdings owned by the firm's } \\
\text { ESOP }\end{array}$} \\
\hline & & & Minimum & Maximum & Mean \\
\hline \multicolumn{6}{|c|}{ Panel A: Pre-expiration years } \\
\hline-3 & $62^{a}$ & 4 & $0.00 \%$ & $10.40 \%$ & $0.53 \%$ \\
\hline-2 & $76^{\mathrm{a}}$ & 5 & $0.00 \%$ & $10.40 \%$ & $0.65 \%$ \\
\hline-1 & 88 & 9 & $0.00 \%$ & $11.90 \%$ & $0.79 \%$ \\
\hline $\begin{array}{l}\text { Mean for years } \\
-3,-2 \text { and }-1\end{array}$ & 88 & 9 & $0.00 \%$ & $10.40 \%$ & $0.60 \%$ \\
\hline \multicolumn{6}{|c|}{ Panel B: Post-expiration years } \\
\hline 1 & 88 & 10 & $0.00 \%$ & $11.90 \%$ & $1.04 \%$ \\
\hline 2 & $58^{\mathrm{a}}$ & 7 & $0.00 \%$ & $12.30 \%$ & $1.07 \%$ \\
\hline 3 & $32^{a}$ & 6 & $0.00 \%$ & $11.70 \%$ & $1.57 \%$ \\
\hline $\begin{array}{l}\text { Mean for years } \\
1,2, \text { and } 3\end{array}$ & 88 & 13 & $0.00 \%$ & $11.97 \%$ & $1.23 \%$ \\
\hline $\begin{array}{l}\text { Percentage point difference } \\
\text { in pre- and post-expiration } \\
\text { means }\end{array}$ & 88 & 10 & & & 0.63 \\
\hline$t$-statistic ${ }^{\mathrm{b}}$ & & & & & $3.04^{\mathrm{c}}$ \\
\hline
\end{tabular}

a For firms converting during 1983,1984, 1986, and 1987, fewer than three years of ownership data are available

either before or after expiration of the antitakeover provisions. See figure 1.

b Test statistic for significant differences between the mean for pre-expiration years $-3,-2$, and -1 and the mean for

post-expiration years 1,2 , and 3 .

${ }^{\mathrm{c}}$ Statistically significant difference at the $1.0 \%$ level. 
Table 9

The effect on firm performance of changes in ownership of publicly traded thrifts from the three years preceding to the three years following the expiration of regulatory restrictions on firm ownership structure.

These restrictions limit ownership by any person or group of persons acting in concert to $10 \%$ of the firm's outstanding shares and by the firm's ESOP to $25 \%$ of outstanding shares during the five years following conversion from mutual to stock organization.

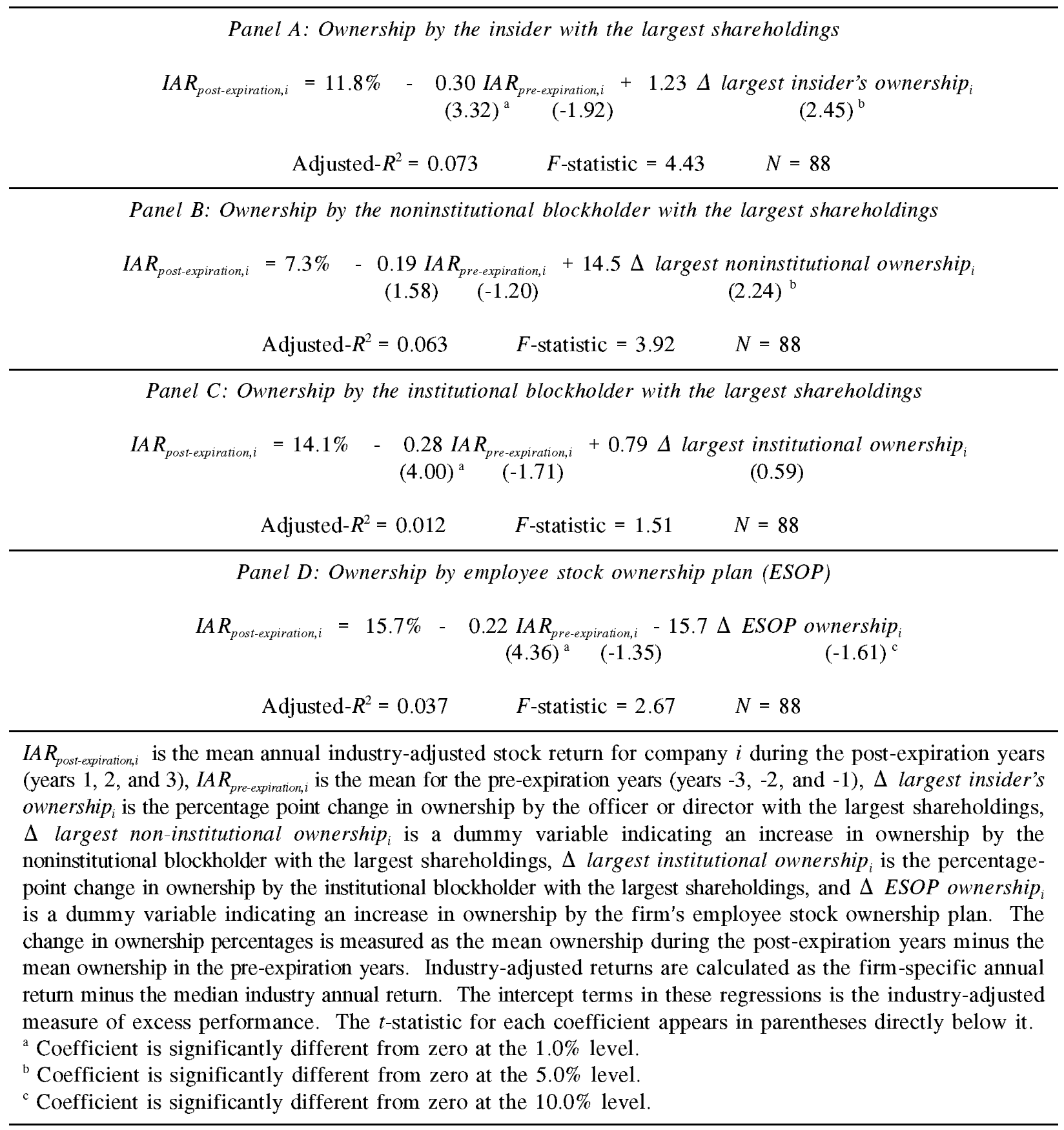


Figure 1.

Availability of ownership data before and after expiration of five-year anti-takeover protection for thrifts converting from mutual to stock ownership in 1983-87.

Ownership data were collected for calendar years 1987-93, so that at least one year of ownership data is available before and after expiration of the anti-takeover protection for each converting thrift. Years $-3,-2$, and -1 comprise the pre-expiration period, and years $+1,+2$, and +3 comprise the post-expiration period.

\begin{tabular}{|c|c|c|c|c|c|c|c|c|c|c|c|c|}
\hline & & & & \multicolumn{3}{|c|}{$1<$} & \multicolumn{6}{|c|}{ ownership data available } \\
\hline 1983 & 1984 & 1985 & 1986 & 1987 & 1988 & 1989 & 1990 & 1991 & 1992 & 1993 & 1994 & 1995 \\
\hline \multirow[t]{5}{*}{ C } & & -3 & -2 & -1 & $\mathbf{E}$ & +1 & +2 & +3 & & & & \\
\hline & C & & -3 & -2 & -1 & $\mathbf{E}$ & +1 & +2 & +3 & & & \\
\hline & & C & & -3 & -2 & -1 & $\mathbf{E}$ & +1 & +2 & +3 & & \\
\hline & & & $\mathrm{C}$ & & -3 & -2 & -1 & $\mathbf{E}$ & +1 & +2 & +3 & \\
\hline & & & & $\mathbf{C}$ & & -3 & -2 & -1 & $\mathbf{E}$ & +1 & +2 & +3 \\
\hline
\end{tabular}

Note: $\mathbf{C}$ denotes the year of conversion, and $\mathbf{E}$ denotes the year that antitakeover protection expired. 